\title{
mHealth Applications, Older People and Type 2 Diabetes-a Detailed Review using Systematic Methodology
}

\author{
Sinclair $\mathrm{AJ}^{1 *}$, Abdelhafiz $\mathrm{A}^{2}$ and Cukierman-Yaffe $\mathrm{T}^{3}$ \\ ${ }^{1}$ Foundation for Diabetes Research in Older People, Diabetes Frail, and King's College, London, UK \\ ${ }^{2}$ Rotherham District General Hospital, South Yorkshire, UK \\ ${ }^{3}$ Endocrinology Institute, Sheba medical centre, Herczeg Institute on Aging, The Epidemiology Department, Sackler School of Medicine, Tel Aviv \\ University, Israel
}

*Corresponding author: Sinclair AJ, Diabetes Study Group, Foundation for Diabetes Research in Older People, Diabetes Frail, and King's College, London, UK, Tel: 0044 (0)1582 738464; E-mail: sinclair.5@btinternet.com

Received: 15 Feb, 2019 | Accepted: 07 Mar, 2019 | Published: 12 Mar, 2019

Citation: Sinclair AJ, Abdelhafiz A, Cukierman-Yaffe T (2019) mHealth Applications, Older People and Type 2 Diabetes-a Detailed Review using Systematic Methodology. J Diab Res Ther 5(1): dx.doi.org/10.16966/2380-5544.141

Copyright: (C) 2019 Sinclair AJ, et al. This is an open-access article distributed under the terms of the Creative Commons Attribution License, which permits unrestricted use, distribution, and reproduction in any medium, provided the original author and source are credited.

\section{Abstract}

Introduction: Smartphone use among older people continues to increase and may provide a modern support mechanism for enhancing self-diabetes care and subsequently improving clinical outcomes.

Objectives: We decided to produce a detailed review of the literature using a systematic evidenced-based approach and assess the benefits and limitations of their clinical efficacy and usability of mHealth applications (including smart phones) in older individuals ( $\geq 55$ years) with type 2 diabetes in randomised Controlled Clinical Trials (RCTs) and to identify future research directions in this area.

Methods: We identified 15 RCTs which matched our selection and inclusion criteria and using a highly descriptive approach, we reviewed changes in areas such as changes in $\mathrm{HbA1c}$, blood pressure, lipid measures, physical activity levels, user satisfaction and self-behaviour changes.

Results: Improvements in metabolic measures including $\mathrm{HbA1c}$, body weight, physical activity, blood pressure and lipid profile were observed. Some improvements were noted in diabetes knowledge, patient satisfaction and personal behaviour and mHealth applications were noted to be useful in some cases of self-titration of hypoglycaemic medications but this was based on limited evidence only. Unfamiliarity, skills and technique acquisition with the mobile app were the main factors for dropouts.

Conclusions: This review revealed that there was a lack of longer-term studies ( $>1$ year), and few studies in people aged 70 years and over! In addition, few studies had a nurse or therapist support mechanism as part of the intervention. The review suggests the need for longer term intervention studies that involve personalised diabetes management programmes and an assessment of their cost-effectiveness.

Keywords: mHealth apps; Older people; Type 2 diabetes; Smartphone; Randomised controlled trails; RCTs; Review; HbA1c

\section{Introduction}

The International Diabetes Federation has predicted that the number of individuals aged 20-79 years is expected to rise to 642 million by 2040 [1]. This has led to a surge of interest in the potential use of telehealth to aid the treatment of diabetes. The advances in technologies plus the higher, and rising, rates of access to them has given the opportunity to increase both efficiency in overall diabetes care and patient self-management. The hope is that this can ease the burden on care givers and solve some of the problems associated with traditional treatment methods such as poor medication adherence, inadequate motivational support and a lack of glycaemic control [2]. A recent meta-review into Telehealth Interventions that supported self-management in long-term conditions including diabetes found that while results did not show consistently superior results to usual care, there were no inferior outcomes and the most highly-weighted diabetes reviews showed, that in type 2 diabetes, glycaemic control was improved when blood glucose telemonitoring that included educational and lifestyle support was administered [3].

Smartphone use among older people continues to increase, OFCOM (Office of Communications) reported in 2017 that in the UK, $39 \%$ of those aged $65-74$ used a smartphone, an $11 \%$ rise compared to the year before [4]. Those older people with both smartphones and diabetes would have access to a large number of apps released with the intention of aiding their self-management. A systematic review of these apps, focusing on their usability for people with diabetes over the age of 50, concluded, that while many of the apps with only 1 or 2 functions did have good usability, this was less true for multifunctional apps and that overall the apps would benefit from more input from both users and care-givers [5]. This was backed up by a qualitative review of mobile apps for people aged 50 or older with 
diabetes that further posited that any app should be individually adaptable due to the lack of heterogeneity found in the population with diabetes and that any successful app should offer personal contact with a health professional, particularly during the first weeks of use [6].

There is evidence of increasing use of mobile phone applications to support control in chronic disease states, including diabetes with improvements in glycaemic control observed to a greater extent in those with type 2 diabetes compared with type 1 diabetes [7]. Nurses tend to favour mobile applications that support chronic disease management whilst doctors tend to prefer applications that manage symptom control and treatment of disease [8].

Two recent systematic reviews have examined the effects of mHealth apps on diabetes care and self-management, usability and clinical effectiveness $[9,10]$. In one review, based on an analysis of 13 randomised controlled trials (RCTs), mHealth app-based interventions were shown to have a modest HbAlc-lowering action $(-0.4 \%,-4.37$ $\mathrm{mmol} / \mathrm{mol}$ ) but no effects on blood pressure, serum lipids, or weight [9]. The second review based on 17 studies, demonstrated satisfaction ratings for experts and patients ranging from $38-80 \%$, but usability ratings were diverse, even dismal in some cases, but reductions in $\mathrm{HbAlc}$ ranged from $0.15 \%$ to $1.9 \%$. Specific enquiry into the efficacy and usability in older people were not studied, however [10].

The effect of a smartphone-based care system for 172 patients (average age range 57-60 years) with type 2 diabetes was recently studied in a 24-week RCT in which HbAlc levels on admission to the study were between $7-10 \%(53-86 \mathrm{mmol} / \mathrm{mol})$ [11]. Compared with a control group, the group employing modules comprising glucose monitoring, diet, physical activity and a clinical decision support platform, there was a significant fall in the adjusted means of Hbalc of $0.35 \%, p=0.001$ ) but no difference in the number of severe hyperglycaemia or hypoglycaemia between the groups.

\section{Objectives of Review}

The major objectives of this detailed review of smartphone apps in diabetes care was to (1) assess the benefits and limitations of their clinical efficacy and usability in older individuals ( $\geq 55$ years) with type 2 diabetes in RCTs and (2) to identify future research directions in this area.

\section{Search strategy}

Published reports of randomized controlled trials that tested the efficacy of a smartphone app in older individuals ( $\geq 55$ years) with type 2 diabetes were sought by systematically searching a variety of biomedical databases, discussion with experts, and examination of the bibliographies of relevant articles. A literature search was conducted in three databases, EMBASE, the Cochrane Library, and Pubmed to identify relevant studies from 2005 to December 2018. A combination of the following MESH terms and keywords were used to conduct the search: type 2 diabetes mellitus, glycaemic control, self-management, self-care, smartphone, tele-medicine mobile applications and randomized controlled trials.

\section{Inclusion and exclusion criteria}

Included were 1) Parallel randomized controlled trials of individuals with type 2 diabetes; 2 ) That tested the efficacy of an app; 3) Assessed outcomes that were either life-style outcomes (physical activity, diet, physical fitness etc.) quality of life or diabetes related outcome (HbA1c, self-care capacity etc.); 4) Included individuals with a mean age of 55 years or over or reported a subgroup analyses of older subjects $(\geq 55$ years); 6) were written in English

Excluded were studies with a 1) Follow-up shorter than 3 months and 2) Studies pertaining to individuals with diabetes type 1;3) Studies reporting on the same trial; 4) Trials that did not include an interactive app (for example only generic SMS reminders, or CGM readings on the cell phone screen).

\section{Data abstraction}

The abstracts and titles of retrieved article were reviewed and inclusion exclusion criteria were employed by two independent reviewers. For studies meeting inclusion criteria data pertaining to size of study $(\mathrm{N})$, duration of study, location of trial, type of application, type of feedback, outcomes assessed and results was collected using data abstraction sheets. The quality of included studies was assessed using elements from the Cochrane collaboration tool including randomization, allocation concealment, blinding of participants and personal of outcome assessors and incomplete outcome ascertainment.

\section{Results}

A description of all RCTs reviewed is given in Table 1. Overall methodological quality of studies was low. Only 2 studies reported on method used for allocation concealment, none of the studies reported if blinding of outcome assessors and data analysts were conducted and loss to follow-up ranged from $10-50 \%$. In a Finnish RCT which included 250 patients with type 2 diabetes, intervention with a mobile phone-based health coaching program supported by a remote monitoring system for one year was associated with a significant improvement in waist circumference in the intervention group but no change in health related quality of life [12]. There was also a non-significant improvement in blood pressure and lipid profile. Withdrawal from the study of some participants was related to the unfamiliarity with the use of mobile phones [12]. Skill acquisition as an independent factor for perceived benefit has also been demonstrated in a Norwegian study [13]. This suggests that appropriate skills are needed prior to application of electronic health technology. A cluster randomised clinical trial in the Netherlands showed that intervention with a combination of a feedback tool and a Self-Management Support Program (SSP) has resulted in a significant increase in physical activity in patients with diabetes compared with usual care or SSP alone [14]. Although multicentre Korean and Chinese studies have shown a significant $0.35 \%$ and $1.16 \%$ reductions in $\mathrm{HbAlc}$ respectively in patients who used a smart phone-based system compared with a usual paper logbook care system, these findings have not been demonstrated in other Norwegian and American studies [11,15-17]. In a Japanese RCT, a remote health monitoring system (DialBetics) was superior to usual care in achieving better glycaemic control [18]. A remote system was also proven feasible to assist in self-titration of oral hypoglycaemic medications [19]. In a British RCT study, an m-health system showed no significant reduction in $\mathrm{HbAlc}$ in the intention to treat analysis, but there was significant benefit in the subgroup who completed the study suggesting that patients with poorer control could be targeted for this intervention [20]. In a Finnish RCT, sophisticated remote patient reporting linked with a health behaviour change automated feedback system not only improved glycaemic control but also resulted in weight reduction compared with the control group [21]. This has been replicated in other two Korean RCTs, which showed improvement in multiple metabolic parameters in the intervention groups using a ubiquitous chronic disease care with or without a clinical decision support system in comparison with controls [22,23]. Significant improvement in metabolic profiles with non-significant reductions in HbAlc was demonstrated in a Spanish RCT, which used a tele-assistance system in the intervention group [24]. Seto and colleagues reviewed data from two Canadian studies which showed little effect of mobile telemonitoring on blood pressure or blood glucose reduction in one study but some benefit on blood pressure control in the other [25]. 
Table 1: RCTs exploring the use of mobile phones in older people (age $\geq 55$ years) with type 2 diabetes mellitus.

\begin{tabular}{|c|c|c|c|c|}
\hline Study & $\begin{array}{l}\text { Subjects/ } \\
\text { duration }\end{array}$ & Age (Y) & Aim to & Main findings \\
\hline $\begin{array}{l}\text { Karhula T, et } \\
\text { al. [12]. }\end{array}$ & $\begin{array}{l}250 \text { patients } \\
\text { with } \mathrm{DM}, \mathrm{F} / \mathrm{U} 1 \mathrm{Y} \text {. }\end{array}$ & $\begin{array}{l}\text { Mean }(S D) \\
\text { age } 66.6 \\
(8.2)\end{array}$ & $\begin{array}{l}\text { Study whether mobile } \\
\text { phone based health } \\
\text { program would improve } \\
\text { HRQL and/or clinical } \\
\text { measures. }\end{array}$ & $\begin{array}{l}\text { A. Significant improvement in waist circumference (beta }-1.71,95 \% \\
\mathrm{Cl}-3.04 \text { to }-0.38, \mathrm{p}=0.01 \text { ). } \\
\text { B. No change in clinical measures including } \mathrm{HbA} 1 \mathrm{c} \text {, weight, } \mathrm{BP} \text { and } \\
\text { lipid profile. } \\
\text { C. No change in HRQL. } \\
\text { D. } 21(8.4 \%) \text { patients dropped out largely due to unfamiliarity with } \\
\text { mobile phones. }\end{array}$ \\
\hline $\begin{array}{l}\text { Torbjornsen A, } \\
\text { et al. [13] }\end{array}$ & $\begin{array}{l}101 \text { patients } \\
\text { with } \mathrm{DM}, \mathrm{F} / \mathrm{U} 1 \mathrm{Y} .\end{array}$ & $\begin{array}{l}\text { Median age } \\
59 \text { (range } \\
35-80)\end{array}$ & $\begin{array}{l}\text { Explore associations of } \\
\text { acceptability of a mobile } \\
\text { diabetes app and ability of } \\
\text { self-management. }\end{array}$ & $\begin{array}{l}\text { After adjustment for age, gender, and frequency of use, only skill and } \\
\text { technique acquisition was independently associated with perceived } \\
\text { benefit. }\end{array}$ \\
\hline $\begin{array}{l}\text { van der } \\
\text { Weegen S, et } \\
\text { al. [14] }\end{array}$ & $\begin{array}{l}190 \text { patients } \\
\text { (117 of them } \\
\text { with } \mathrm{DM} \text { ), } \\
\text { divided into } 3 \\
\text { groups, F/U } 9 \mathrm{M} \text {. }\end{array}$ & $\begin{array}{l}\text { Average age } \\
58 .\end{array}$ & $\begin{array}{l}\text { Evaluate whether } \\
\text { SSP+feedback tool leads } \\
\text { to more physical activity } \\
\text { compared to SSP alone or } \\
\text { usual care. }\end{array}$ & $\begin{array}{l}\text { A. Group } 1 \text { (tool+SSP) showed more physical activity time than } \\
\text { group } 3 \text { (usual care), mean difference } 11.73 \text { minutes, } 95 \% \mathrm{Cl} 6.21 \\
\text { to } 17.25, \mathrm{p}<0.001 \text { and group } 2 \text { (SSP alone), } 7.86,2.18 \text { to } 13.54 \text {, } \\
\mathrm{p}=0.003 \text {. } \\
\text { B. Difference was maintained } 3 \text { months after intervention, } 10.59 \text {, } \\
4.94 \text { to } 16.25, \mathrm{p}<0.001 \text { compared to group } 3 \text { and } 9.41,3.70 \text { to } \\
15.11, p<0.001 \text { compared to group } 2 \text {. } \\
\text { C. There was no difference between group } 2 \text { and } 3 \text {. }\end{array}$ \\
\hline $\begin{array}{l}\text { Kim EK, et al. } \\
{[11]}\end{array}$ & $\begin{array}{l}191 \text { patients } \\
\text { with } D M, F / U \\
6 \mathrm{M} \text {. }\end{array}$ & $\begin{array}{l}\text { Average age } \\
58 .\end{array}$ & $\begin{array}{l}\text { Compare mobile phone } \\
\text { (mDiabetes) to paper } \\
\text { logbook (plogbook) care } \\
\text { systems on HbA1c. }\end{array}$ & $\begin{array}{l}\text { Compared to plogbook, mDiabetes group had: } \\
\text { A. Significant } \mathrm{HbA} 1 \mathrm{c} \text { reduction } 0.40(0.09 \%) \text { v } 0.06(0.10 \%) \text {. } \\
\text { B. } 41.1 \% \text { participants with } \mathrm{HbA} 1 \mathrm{c}<7.0 \% \text { v } 20.7 \% \text {. } \\
\text { C. No significant difference in hypo or hyperglycaemic events. }\end{array}$ \\
\hline $\begin{array}{l}\text { Zhou W, et al. } \\
{[15]}\end{array}$ & $\begin{array}{l}100 \text { patients } \\
\text { with } D M, F / U \\
3 \mathrm{M} \text {. }\end{array}$ & $\begin{array}{l}\text { Mean }(S D) \\
\text { age } 55(13)\end{array}$ & $\begin{array}{l}\text { Evaluate impact of smart } \\
\text { phone-based diabetes } \\
\text { system on metabolic } \\
\text { control. }\end{array}$ & $\begin{array}{l}\text { A. HbA1c reduced significantly in in intervention group } 1.95 \% \mathrm{v} \\
0.79 \%, p=0.001 \text {. } \\
\text { B. Patient's satisfaction and diabetes knowledge and behaviours } \\
\text { were better in intervention group. } \\
\text { C. No difference in in weight, blood pressure or lipid profile. }\end{array}$ \\
\hline $\begin{array}{l}\text { Holmen } \mathrm{H} \text {, et } \\
\text { al. [16] }\end{array}$ & $\begin{array}{l}151 \text { patients } \\
\text { with } \mathrm{DM}, \mathrm{F} / \mathrm{U} 1 \mathrm{Y} \text {. }\end{array}$ & $\begin{array}{l}\text { Average age } \\
57 .\end{array}$ & $\begin{array}{l}\text { Test whether mobile } \\
\text { phone } \pm \text { health counselling } \\
\text { improve glycaemic control } \\
\text { compared to control. }\end{array}$ & $\begin{array}{l}\text { A. HbA1c decreased in the } 3 \text { groups with no significant difference. } \\
\text { B. Skill acquisition was significantly greater in the mobile } \\
\text { phone+health-counselling group, } \mathrm{p}=0.04 \text {. } \\
\text { C. Those aged } \geq 63 \text { years used the app more than younger } \\
\text { counterparts, OR } 2.7,95 \% \mathrm{Cl} 1.02 \text { to } 7.12, \mathrm{p}=0.045 \text {. }\end{array}$ \\
\hline $\begin{array}{l}\text { Forjuoh SN, et } \\
\text { al. [17] }\end{array}$ & $\begin{array}{l}376 \text { patients } \\
\text { with } D M, F / \cup 1 Y \text {. }\end{array}$ & $\begin{array}{l}25 \% \text { of } \\
\text { patient's } \geq \\
65\end{array}$ & $\begin{array}{l}\text { Compare effectiveness of } \\
\text { CDSMP, PDA, combination } \\
\text { of both and control. }\end{array}$ & $\begin{array}{l}\text { A. HbA1c reductions for CDSMP, PDA, CDSMP+PDA and control } \\
\text { were } 1.1 \%, 0.7 \%, 1.1 \% \text {, and } 0.7 \% \text {, respectively. } \\
\text { B. There was no significant difference in } \mathrm{HbA} 1 \mathrm{c} \text { reductions between } \\
\text { all groups, } \mathrm{p}=0.78 \text {. }\end{array}$ \\
\hline $\begin{array}{l}\text { Waki K, et al. } \\
\text { [18] }\end{array}$ & $\begin{array}{l}54 \text { patients with } \\
\text { DM, F/U } 3 \mathrm{M} .\end{array}$ & $\begin{array}{l}\text { Mean (SD) } \\
\text { age } 57.3 \\
(9.7)\end{array}$ & $\begin{array}{l}\text { Assess remote health } \\
\text { data monitoring system } \\
\text { (DialBetics) on clinical } \\
\text { outcomes. }\end{array}$ & $\begin{array}{l}\text { In DialBetics compared to control group: } \\
\text { A. HbA1c decreased by } 0.4 \% \mathrm{v} \text { increase in control group by } 0.1 \% \text {, } \\
\mathrm{p}=0.02 \text {. } \\
\text { B. FBS decreased by } 0.3 \mathrm{mmol} / \mathrm{I} v \text { increase in control group by } 0.9 \\
\mathrm{mmol} / \mathrm{l}, \mathrm{p}=0.02 \text {. } \\
\text { C. Non-significant improvement in } \mathrm{BMI} \text {. }\end{array}$ \\
\hline $\begin{array}{l}\text { Nagrebetsky } \\
\text { A, et al. [19] }\end{array}$ & $\begin{array}{l}14 \text { patients with } \\
\text { DM, F/U } 1 \text { Y. }\end{array}$ & $\begin{array}{l}\text { Mean }(S D) \\
\text { age } 58(11)\end{array}$ & $\begin{array}{l}\text { Explore feasibility of mobile } \\
\text { phone-guided self-titration } \\
\text { of oral hypoglycaemic } \\
\text { drugs. }\end{array}$ & $\begin{array}{l}\text { A. Mobile phone-guided self-titration of hypoglycaemic medications } \\
\text { is feasible. } \\
\text { B. Median (IQR) change in } \mathrm{HbA} 1 \mathrm{c}-0.9 \% \text { ( }-1.9 \% \text { to } 0 \%) \text { in intervention } \\
\text { group and }-0.5 \%(-1.2 \% \text { to } 0.6 \%) \text { in control group. }\end{array}$ \\
\hline $\begin{array}{l}\text { Istepanian } \\
\text { RSH, et al. } \\
{[20]}\end{array}$ & $\begin{array}{l}137 \text { patients } \\
\text { with } \mathrm{DM}, \mathrm{F} / \mathrm{U} \\
9 \mathrm{M} \text {. }\end{array}$ & $\begin{array}{l}\text { Mean }(S D) \\
\text { age } 60(12)\end{array}$ & $\begin{array}{l}\text { Evaluate an } \mathrm{m} \text {-health } \\
\text { system against usual care } \\
\text { on glycaemic control. }\end{array}$ & $\begin{array}{l}\text { A. In ITT analysis no difference between both groups found. } \\
\text { B. In PP analysis } \mathrm{HbA} 1 \mathrm{c} \text { was significantly lower in intervention group } \\
(7.7 \% \text { v } 8.4 \%, p=0.06) \text {. }\end{array}$ \\
\hline $\begin{array}{l}\text { Orsama AL, et } \\
\text { al. [21] }\end{array}$ & $\begin{array}{l}48 \text { patients with } \\
\text { DM, F/U } 10 \mathrm{M} .\end{array}$ & $\begin{array}{l}\text { Average age } \\
62 .\end{array}$ & $\begin{array}{l}\text { Evaluate remote patient } \\
\text { reporting and automated } \\
\text { telephone feedback system. }\end{array}$ & $\begin{array}{l}\text { Compared to control, intervention group achieved significant reduction in: } \\
\text { A. HbA1c }-4.0 \%(95 \% \mathrm{Cl}-0.67 \text { to }-0.14 \%) \text { v } 0.036 \%(-0.23 \% \text { to } 0.30 \%) \text {. } \\
\text { B. Weight }-2.1 \mathrm{~kg}(-3.6 \text { to }-0.6 \mathrm{~kg}) \text { v } 0.4 \mathrm{~kg}(-1.1 \text { to } 1.9 \mathrm{~kg}) \text {. }\end{array}$ \\
\hline $\begin{array}{l}\operatorname{Lim} S \text {, et al. } \\
{[22]}\end{array}$ & $\begin{array}{l}100 \text { patients } \\
\text { with } \mathrm{DM}, \mathrm{F} / \mathrm{U} \\
6 \mathrm{M} \text {. }\end{array}$ & Age $>60$. & $\begin{array}{l}\text { Assess UCDC+CDSS on } \\
\text { glycaemic control and } \\
\text { metabolic parameters. }\end{array}$ & $\begin{array}{l}\text { A. Intervention group showed significant reduction in } \mathrm{HbA} 1 \mathrm{c} \text {, body } \\
\text { fat mass, and improvement in lipid profile. } \\
\text { B. HbA1c<7.0\% (without hypoglycaemia) was significantly higher in } \\
\text { intervention group ( } 26 \% \text { v } 12 \%, \mathrm{p}<0.05) \text {. }\end{array}$ \\
\hline $\begin{array}{l}\text { Yoo HJ, et al. } \\
{[23]}\end{array}$ & $\begin{array}{l}123 \text { patients } \\
\text { with } \mathrm{DM}, \mathrm{F} / \mathrm{U} \\
3 \mathrm{M} \text {. }\end{array}$ & $\begin{array}{l}\text { Average age } \\
58 .\end{array}$ & $\begin{array}{l}\text { Investigate efficacy of UCDC } \\
\text { system using mobile phone. }\end{array}$ & $\begin{array}{l}\text { Intervention group showed significant reduction in } \mathrm{HbA} 1 \mathrm{c} \text {, blood } \\
\text { pressure, and improvement in lipid profile. }\end{array}$ \\
\hline
\end{tabular}




\begin{tabular}{|c|c|c|c|c|}
\hline $\begin{array}{l}\text { Rodríguez- } \\
\text { Idı'goras MI, } \\
\text { et al. [24] }\end{array}$ & $\begin{array}{l}328 \text { patients } \\
\text { with } \mathrm{DM}, \mathrm{F} / \mathrm{U} 1 \mathrm{Y} .\end{array}$ & $\begin{array}{l}\text { Average age } \\
64 .\end{array}$ & $\begin{array}{l}\text { Evaluate impact of a } \\
\text { teleassistance system on } \\
\text { metabolic control. }\end{array}$ & $\begin{array}{l}\text { A. Non-significant reduction in } \mathrm{HbA1c} \text {. } \\
\text { B. Significant reduction in blood pressure, lipids and body weight. }\end{array}$ \\
\hline $\begin{array}{l}\text { Seto } E \text {, et al. } \\
{[25]}\end{array}$ & $\begin{array}{l}2 \text { RCTs, F/U } \\
\text { M, number of } \\
\text { patients: } \\
\text { A. } 33 . \\
\text { B. } 26 .\end{array}$ & $\begin{array}{l}\text { Mean (SD) } \\
\text { age: } \\
\text { A. } 58.1(9.9) \text {. } \\
\text { B. } 63.7(8.7) \text {. }\end{array}$ & $\begin{array}{l}\text { Assess effectiveness of } \\
\text { telemonitoring on: } \\
\text { A. Blood pressure. } \\
\text { B. Blood pressure and } \\
\text { blood glucose. }\end{array}$ & $\begin{array}{l}\text { A. Average blood pressure dropped } 9 / 3 \mathrm{mmHg}(p<0.001 / 0.005) \text {. } \\
\text { B. No significant decrease in blood pressure or blood glucose. }\end{array}$ \\
\hline
\end{tabular}

RCTs=Randomised Controlled Trials, Y=Years, DM=Diabetes Mellitus, SD=Standard Deviation, F/U=Follow Up, HRQL=Health Related Quality Of Life, $\mathrm{Cl}=$ Confidence Interval, $\mathrm{M}=$ Months, SSP=Self-Management Support Program, FBS=Fasting Blood Sugar, BMI=Body Mass Index, OR=Odds Ratio, CDSMP = Chronic Disease Self-Management Program, PDA=Personal Digital Assistant, IQR=Inter Quartile Range, ITT=Intention To Treat Analysis, $\mathrm{PP}=$ Per Protocol Analysis, UCDC=Ubiquitous Chronic Disease Care, CDSS=Clinical Decision Support System.

\section{Discussion and Conclusion}

We have performed a detailed review of randomised controlled trials involving older participants ( $\geq 55$ years) with type 2 diabetes mellitus to assess the effects of mHealth apps on clinical efficacy (e.g. measured by changes in $\mathrm{HbAlc}$, blood pressure, lipid measures) and their usability. Other parameters such as physical activity levels, user satisfaction and self-behaviour changes were measured in some studies.

In Box 1 (a), we have summarised the key changes noted which suggest that $\mathrm{mHealth}$ applications in older people with diabetes can have beneficial effects in enhancing glucose control with $\mathrm{HbAlc}$ reductions likely to be of clinical benefit (>1.0\%), increasing physical activity, and in general bring about modest benefits also in blood pressure and lipid control. Weight change when measured also showed some beneficial effects but quality of life measures were little employed. Behaviour change was not studied in most studies although when measured was found to have been influenced positively [5]. Whilst providing some encouraging results for promoting diabetes self-management, the limitations of the studies reviewed do not yet provide convincing evidence that smartphone apps use in ageing individuals with type 2 diabetes can influence chronic disease management outcomes or selfcare behaviours sufficient to warrant widespread implementation in routine clinical practice.

A previous systematic review of diabetes mobile applications has suggested that patients with type 2 diabetes older than 55 years (the threshold age in our review), took greater time in adapting to the use of the diabetes management software and its accompanied website, and that many apps did not meet sufficient standards of health literacy such as clear images, easily readable text and interpretable information-all of which may have significant consequences for older patients troubled by visual problems or changes in mental performance or manual dexterity making navigation on the app difficult [10].

Our detailed review has established that several limitations in the medical literature are present in the use of mobile apps in diabetes care (Box 1 (b). These findings suggest the need for longer duration intervention trials in people with type 2 diabetes who are better characterised in terms of physical limitations and functional characteristics, and establish the need for more patient-relevant outcomes such as health related quality of life. Future studies should attempt to explore the use of mobile apps in varying populations of different cultures and socioeconomic backgrounds, and undertake robust evaluations of cost-effectiveness.

We agree with previous authors that future studies should also examine the benefits of enhancing motivation to participate in mHealth application programmes although to make this feasible, further in-depth research into diabetes health behaviours are required $[10,26]$. The use of cognitive rehabilitation training may also provide
Box 1: (a) Summary of RCTs 'outcomes for the use ofrs) with type 2 diabetes mellitus; (b) Current limitations of the use of Smartphone apps in older people ( $>55$ years)

(a)

- Overall, improvements in metabolic measures including $\mathrm{HbA} 1 \mathrm{c}$, body weight, physical activity, blood pressure and lipid profile.

- Some improvements were noted in diabetes knowledge, patient satisfaction and personal behaviour.

- Useful in self-titration of hypoglycaemic medications based on limited evidence only.

- Unfamiliarity, skills and technique acquisition with the mobile app were the main factors for dropouts.

(b)

- Studies of low methodological quality

- Few studies are in people aged 70 years and over!

- Interventions are usually 1 year or less

- Patients with type 2 are not generally characterised in term of physical or cognitive status

- Few studies only have nurse or therapist support mechanisms

- Few studies measure other patient-centred outcomes such quality of life, functional change, health behaviour change, or adherence to the programme

- Few have had fully personalised diabetes management programmes developed

- Virtual absence of cost-effectiveness evaluation of the use of mobile apps in diabetes care

RCTs=Randomised Controlled Trials.

support for patients with type 2 diabetes in the area of self-care and daily functioning and if adapted to be used in a diabetes app, patients would have a readily accessible cognitive strategy available to them on a daily basis [27].

In summary, mobile diabetes apps offer increasing opportunities for enhancing diabetes self-care in older adults but it is likely that for maximum benefits to be realised they will need two key requirements: firstly, the support and close liaison with a trained health professional who is based in an accessible clinic or in primary/community care, and a management programme that is 'personalised' so that goals of care are intimately linked to clinical need and the functional/comorbid characteristics of the patient.

\section{References}

1. Ogurtsova K, da Rocha Fernandes JD, Huang Y, Linnenkamp U, Guariguata L, et al. (2017) IDF Diabetes Atlas: Global estimates for the prevalence of diabetes for 2015 and 2040. Diabetes Res Clin Pract 128: 40-50.

2. Ashrafzadeh S, Hamdy O (2018) Patient-Driven Diabetes Care of the Future in the Technology Era. Cell Metab 29: 564-575. 
3. Hanlon $\mathrm{P}$, Daines $\mathrm{L}$, Campbell $\mathrm{C}$, McKinstry B, Weller $\mathrm{D}$, et al. (2017) Telehealth Interventions to Support Self-Management of Long-Term Conditions: A Systematic Metareview of Diabetes, Heart Failure, Asthma, Chronic Obstructive Pulmonary Disease, and Cancer. J Med Internet Res 19: e172.

4. Ofcom (2017) Rise of the Social Seniors revealed

5. Arnhold M, Quade M, Kirch W (2014) Mobile applications for diabetics: a systematic review and expert-based usability evaluation considering the special requirements of diabetes patients age 50 years or older. J Med Internet Res 16: e104.

6. Scheibe M, Reichelt J, Bellmann M, Kirch W (2015) Acceptance factors of mobile apps for diabetes by patients aged 50 or older: a qualitative study. Med 2 0. 4: e1.

7. Liang X, Wang Q, Yang X, Cao J, Chen J, et al. (2011) Effect of mobile phone intervention for diabetes on glycaemic control: a metaanalysis. Diabet Med 28: 455-463.

8. Jeon E, Park HA (2015) Nursing Intervention using smartphone technologies; a systematic review and meta-analysis. Stud Health Technol Inform 210: 321-325.

9. Cui M, Wu X, Mao J, Wang Xi, Nie M (2016) T2DM Self-Management via Smartphone Applications: Systematic Review and Meta-Analysis. PLOS one 11: e0166718.

10. Fu H, McMahon SK, Gross CR, Adam TJ, Wyman JF (2017) Usability and clinical efficacy of diabetes mobile applications for adults with type diabetes: a systematic review. Diabetes Res Clin Pract 131: 70-81.

11. Kim EK, Kwak SH, Jung HS, Koo BK, Moon MK, et al. (2019) The Effect of a Smartphone-Based, Patient-Centered Diabetes Care System in Patients with Type 2 Diabetes: A Randomized, Controlled Trial for 24 Weeks. Diabetes Care 42: 3-9.

12. Karhula $\mathrm{T}$, Vuorinen $\mathrm{AL}$, Raapysjarvi $\mathrm{K}$, Pakanen $\mathrm{M}$, Itkkonen $\mathrm{P}$, et al. (2015) Telemonitoring and Mobile Phone-Based Health Coaching among Finnish Diabetic and Heart Disease Patients: Randomized Controlled Trial. J Med Internet Res 17: e153.

13. Torbjørnsen A, Småstuen MC, Jenum AK, Årsand E, Ribu L (2018) Acceptability of an mHealth App Intervention for Persons with Type 2 Diabetes and its Associations with Initial Self-Management: Randomized Controlled Trial. JMIR Mhealth Uhealth 6: e125.

14. van der Weegen $S$, Verwey $R$, Spreeuwenberg $M$, Tange $H$, van der Weijden T, et al. (2015) It's LiFe! Mobile and Web-Based Monitoring and Feedback Tool Embedded in Primary Care Increases Physical Activity: A Cluster Randomized Controlled Trial. J Med Internet Res 17: e184.

15. Zhou W, Chen M, Yuan J, Sun Y (2016) Welltang - A smart phonebased diabetes management application-Improves blood glucose control in Chinese people with diabetes. Diabetes Res Clin Pract 116: 105-110.
16. Holmen $\mathrm{H}$, Torbjørnsen $\mathrm{A}$, Wahl AK, Jenum AK, Smastuen MC, et al. (2014) A Mobile Health Intervention for Self-Management and Lifestyle Change for Persons with Type 2 Diabetes, Part 2: OneYear Results from the Norwegian Randomized Controlled Trial RENEWING HEALTH. JMIR Mhealth Uhealth 2: e57.

17. Forjuoh SN, Bolin JN, Huber Jr JC, Vuong AM, Adepoju OE, et al. (2014) Behavioral and technological interventions targeting glycemic control in a racially/ethnically diverse population: a randomized controlled trial. BMC Public Health 14: 71

18. Waki K, Fujita H, Uchimura Y, Omae K, Aramaki E, et al. (2014) DialBetics-A Novel Smartphone-based Self-management Support System for Type 2 Diabetes Patients. J Diabetes Sci Technol 8: 209-215.

19. Nagrebetsky A, Larsen M, Craven A, Turner J, McRobert N, et al. (2013) Stepwise Self-Titration of Oral Glucose-Lowering Medication Using a Mobile Telephone-Based Telehealth Platform in Type 2 Diabetes: A Feasibility Trial in Primary Care. J Diabetes Sci Technol 7: $123-134$

20. Istepanian RSH, Zitouni K, Harry D, Moutosammy N, Sungoor A, et al. (2009) Evaluation of a mobile phone telemonitoring system for glycaemic control in patients with diabetes. J Telemed Telecare 15: 125-128.

21. Orsama AL, Lähteenmäki J, Harno K, Kulju M, Wintergerst $E$, et al. (2013) Active assistance technology reduces glycosylated hemoglobin and weight in individuals with type 2 diabetes: results of a theorybased randomized trial. Diabetes Technol Ther 15: 662-669.

22. Lim S, Kang SM, Kim KM, Moon JH, Choi SH, et al. (2016) Multifactorial intervention in diabetes care using real-time monitoring and tailored feedback in type 2 diabetes. Acta Diabetol 53: 189-198.

23. Yoo HJ, Park MS, Kim TN, Yang SJ, Cho GJ, et al. (2009) A Ubiquitous Chronic Disease Care system using cellular phones and the internet. Diabet Med 26: 628-635.

24. Rodríguez-Idígoras MI, Sepúlveda-Muñoz J, Sánchez-GarridoEscudero R, Martínez-González JL, Escolar-Castelló JL, et al. (2009) Telemedicine influence on the follow-up of type 2 diabetes patients. Diabetes Technol Ther 11: 431-437.

25. Seto E, Istepanian RS, Cafazzo JA, Logan A, Sungoor A (2009) UK and Canadian Perspectives of the Effectiveness of Mobile Diabetes Management Systems. Conf Proc IEEE Eng Med Biol Soc 2009 6584-6587.

26. Ryan R, Deci E (2000) Self-determination theory and the facilitation of intrinsic motivation, social development, and well-being. Ann Pyschol 55: 68-78.

27. Cuevas HE, Stuifbergen AK, Ward C (2018) Participant Perspectives of Cognitive Rehabilitation for Type 2 Diabetes: Expectations and Impact. J Aging Res 2018: 6563457. 